\title{
KETERLIBATAN ORANG TUA DALAM MENGEMBANGKAN KEMAMPUAN MEMBACA PADA ANAK USIA DINI
}

\author{
Ajeng Teni Nur Afriliani, Ocih Setiasih, Ali Nugraha \\ Universitas Pendidikan Indonesia, Jln. Setiabudhi no. 229 Bandung \\ e-mail: ajengteninurafriliani@gmail.com
}

\begin{abstract}
Abstrak : Parental Involvement in Improving Reading AbilityThe aim of this research is to know the parental involvement in improving the children abilityin Cikole regency of Sukabumi. The reseach method used is descriptive survey by communicative approach. The population of the reseach are the parents whose children are studying in group B of the kindergarden in Cikole regency of Sukabumi, the technique of this sample is simple random sampling. Beside that collecting data is as an instrument. The result of this reseach show that the parental imvolment in this region is middle. 1). The paarental involvement position in children ability, 2) the parental involvement reseach in improving reading ability, 3) the parents support to improve their children reading ability, and 4) the parental involvement obstacle in improving reading ability. The recommendations are parents should more active and focus in improving their reading interest. The teachers should collaborate with the parents for the next researcher should be able to do the reseach with the different method.
\end{abstract}

Keyword: parental involvement, reading ability, early childhood.

\begin{abstract}
Abstrak : keterlibatan orang tua dalam mengembangkan kemampuan membaca pada anak usia dini. Penelitian ini bertujuan untuk mengetahui gambaran keterlibatan orang dalam mengembangkan kemampuan membaca pada anak usia dini di Kecamatan Cikole Kota Sukabumi. Metode penelitian yang digunakan adalah survey deskriptif dengan menggunakan pendekatan kuantitatif. Populasi penelitian ini adalah orang tua yang menyekolahkan anak di taman kanak-kanak kelompok B se-Kecamatan Cikole Kota Sukabumi dengan jumlah sampel 234 orang tua. Teknik pengambilan sampel dilakukan dengan menggunakan teknik Simple Random Sampling. Istrumen yang digunakan dalam pengumpulan data berupa kuesioner keterlibatan orang tua yang dikembangkan sendiri oleh peneliti. Hasil penelitian menunjukan bahwa keterlibatan orang tua di kecamatan Cikole kota Sukabumi dalam mengembangkan kemampuan membaca pada anak usia dini sebagian besar berada pada kategori sedang dilihat dari segi 1) Posisi keterlibatan orang tua dalam mengembangkan kemampuan membaca anak usia dini, 2) Alasan terkait kemampuan orang tua terlibat dalam mengembangkan kemampuan membaca anak usia dini, 3) Bentuk usaha yang dilakukan orang tua dalam mengembangkan kemampuan membaca anak usia dini, dan 4) Hambatan yang dihadapi orang tua dalam mengembangkan kemampuan membaca anak. Rekomendasi bagi orang tua hendaknya lebih aktif dan fokus dalam mengembangkan kemampuan membaca pada anak. Bagi guru PAUD diharapkan dapat berkolaborasi dengan orang tua dalam mengembangkan kemampuan membaca pada anak. Bagi peneliti selanjutnya yang meneliti dengan topik yang sama, dapat melakukan penelitian menggunakan metode yang berbeda.
\end{abstract}

Kata Kunci: keterlibatan orang tua, kemampuan membaca, anak usia dini 
Anak usia dini merupakan usia yang memiliki rentang waktu sejak anak lahir hingga usia enam tahun, dimana dilakukan melalui pemberian rangsangan pendidikan untuk membantu pertumbuhan dan perkembangan jasmani dan rohani agar anak memiliki kesiapan dalam memasuki pendidikan lebih lanjut (Mutiah, 2012, hlm. 2). Rentang usia ini merupakan usia yang sangat penting bagi kehidupan manusia, Menurut Wahyudin \& Mubiar (2012, hlm. 6) "Pada rentang usia ini anak mengalami masa keemasan (the golden years) yang merupakan masa dimana anak mulai peka/sensitif untuk menerima berbagai rangsangan. Pada masa atau usia ini dapat juga dikatakan sebagai masa fundamenal bagi kehidupan anak selanjutnya, karena pada masa ini otak anak berkembang dengan sangat pesat sehingga anak mampu menerima informasi dengan sangat cepat. Tentunya unuk memaksimalkan perkembangan pada usia tersebut, maka anak usia dini perlu mendapatkan perhatian yang sangat extra dari lingkungan sekitar kehidupan anak.

Salah satu perkembangan yang tentunya penting untuk anak usia dini adalah perkembangan bahasa anak. Bahasa sangat penting bagi kehidupan manusia tidak terkecuali anak usia dini terutama pada jaman yang semakin modern ini. Menurut Tom \& Harriet Sobol (2003, hlm. 25) menyatakan bahwa diantara usia balita dan taman kanak-kanak, perkembangan bahasa anak merupakan hal yang fenomenal. Hal ini diperkuat oleh Gunara (dalam Dariyo, 2007, hlm. 61) bila kesempatan pada masa emas (golden age) ini tidak memperoleh rangsangan yang tepat, maka perkembangan bahasa anak cenderung tidak maksimal. Sebaliknya bila kesempatan ini dapat dimanfaatkan dengan baik dan orang tua memberi rangsangan yang tepat, maka masa kritis akan menghasilkan perkembangan bahasa yang maksimal.

Peran orang tua dalam pendidikan anak usia dini sangalah besar, karena anak akan lebih banyak menghabiskan wakunya di rumah dibandingkan diluar rumah. Banyak penelitian yang menyatakan bahwa peran orang tua akan sangat berpengaruh terhadap prestasi anak termasuk prestasi dalam kemampuan membaca anak. Seperti yang telah diungkapkan oleh Meece, Seneschal \& Lefevre (dalam Schunk, 2012) "Ada banyak bukti yang mendukung hipotesis bahwa kualitas pembelajaran awal seorang anak di lingkungan keluarga berkaitan positif dengan perkembanga intelegensi dan keterampilan membaca."

Penelitian komisi Bullock (dalam Tampubolon, 1993, hlm. 46) yang dilakukan pada tahun 1975 di Inggris, dengan laporannya yang berjudul A Language For Life (Bahasa Seumur Hidup), menyimpulkan bahwa peranan orang tua sangat menentukan dalam pendidikan anak, teruama pada tingkat Prasekolah dan SD, khususnya dalam membaca dan perkembangan bahasa. Oleh karena itu orang tua hendaknya menyadari kewajibannya dalam pendidikan anak. Orang tua berkontribusi dan tidak menyerahkan pendidikan anak terutama dalam meningkatkan kemampuan membaca anak pada lembaga (sekolah).

Kenyatannya, kebutuhan jaman saat ini menuntut anak unuk mampu membaca lebih cepat. Selain tuntuan jaman, tuntutan orang tua pun menambah kebingungan pada lembaga PAUD, banyak orang tua yang menuntut anak-anaknya mampu membaca sedini mungkin, karena cemas anak-anaknya tidak mampu mengikuti seleksi masuk pada jenjang pendidikan selanjutnya. Oleh sebab itu maka orang tua pun membebankan dan menyerahkan semua ini pada sekolah tanpa peduli dengan perkembangan anak itu 
sendiri. Sehingga pendidikan anak usia dini pada saat ini pun dihadapkan pada bagaimana upaya mengenalkan kemampuan baca tulis sejak dini secara tepat dan aman. Pro kontra permasalahan ini semakin mempersulit posisi anak dan guru, dan akhirnya guru pun tergelincir pada pembelajaran yang berorientasi akademik sehingga prinsip pembelajaran anak usia dini pun sering diabaikan banyak pendidik yang menerapkan sistem pembelajaran membaca dengan metode drill dan dikte. Padahal banyak riset yang menunjukan bahwa drill dan dikte dalam pembelajaran membaca tidak membantu banyak dalam perkembangan membaca anak. Seperti yang telah dipaparkan sebelumnya, tidak sedikit orang tua yang menyerahkan pendidikan anaknya kepada pihak lembaga pendidikan (sekolah) yang mereka percaya. Hal ini sangat disayangkan apabila orang tua menyerahkan begitu saja pendidikan anakanak mereka kepada pihak lain tanpa ikut berkontribusi, karena seperti yang kita tahu, bahwa orang tua adalah pendidik utama dalam pendidikan anak, terutama dalam mengembangkan kemampuan berbahasa termasuk kemampuan membaca bagi anak usia dini.

Indonesia sendiri adalah negara dengan kemampuan membaca anak usia dini yang masih minim, banyak anak yang belum mampu merangkai huruf dan kalimat dengan benar, kosa kata anak yang belum memenuhi kriteria perkembangan membaca anak, sulit mengenali suatu huruf, sulit membedakan huruf yang memiliki bentuk hampir sama seperi b dan d lalu p dan $\mathrm{q}$.

Banyak cara yang dapat dilakukan orang tua dalam mengembangkan kemampuan berbahasa seperti memberikan kebebasan anak unuk membaca gambar, eksplorasi dengan buku, menggambar dan menulis bebas, dan masih banyak lagi.
Menurut Tampubolon (1993, hlm. 45) usaha-usaha yang dapat dilakukan orang tua di rumah dalam meningkakan kemampuan membaca anak seperti memberikan perhatian pada pelajaran anak, bercakapcakap, membaca dan bercerita, menciptakan bacaan, menulis pengalaman dalam buku harian, dan terus membina keluarga pembaca.

\section{METODE}

Penelitian ini merupakan penelitian kuantitatif dengan metode survei deskriptif. Alasan digunakannya metode ini karena penelitian ini bertujuan untuk mengambarkan kondisi keterlibatan orang tua dalam mengembangkan kemampuan membaca anak usia dini di Kecamatan Cikole Kota Sukabumi tanpa memberikan perlakuan.

Variabel dalam penelitian ini adalah variabel tunggal yaitu keterlibatan orang tua dalam mengembangkan kemampuan membaca pada anak usia dini.

Populasi penelitian ini merupakan seluruh orang tua yang menyekolahkan anaknya di Taman Kanak-kanak kelompok B se-Kecamatan Cikole Kota Sukabumi yang berjumlah 651 dari 20 Taman kanakkanak di Kecamatan Cikole.

Sampel dalam penelian ini berjumalah 234 yang diperoleh dengan menggunakan teknik Simple Random Sampling.

Instrumen dalam penelitian ini menggunakan angket tertutup dengan skala Likert (dengan alternatif jawaban: Selalu (SL), Sering (SR), Kadang-kadang (KD), dan Tidak Pernah (TP)). Sebelum disebarkan ke lapangan, dilakukan 2 tahapan uji instrumen, yaitu uji konstruk terhadap 2 orang ahli, dan uji internal terdiri dari uji validitas menggunakan rumus product momen serta uji reliabilitas menggunakan 
rumus spearman brown belahan ganjil genap dengan bantuan SPSS versi 20. Tteknik analisis data yang digunakan dalam penelitian ini adalah analisis statistik deskriptif, karena hasil suvey penelitian ini dilaporkan dan disajikan dalam bentuk tabel, diagram, dan persentase.

\section{HASIL DAN PEMBAHASAN}

Berdasarkan hasil penelitian yang telah dilakukan penulis ditemukan bahwa $10,68 \%$ secara umum keterlibatan orang tua dalam mengembangkan kemampuan membaca pada anak usia dini berada pada ketegori rendah, 84,18\% secara umum keterlibatan orang tua dalam mengembangkan kemampuan membaca pada anak usia dini berada pada ketegori sedang dan 5,12\% secara umum keterlibatan orang tua dalam mengembangkan kemampuan membaca pada anak usia dini berada pada ketegori tinggi.

Untuk lebih jelasnya grafik 1 . berikut menyajikan keterlibaan orang tua secara umum dalam mengembangkan kemampuan membaca pada anak usia dini di Kecamatan Cikole Kota Sukabumi.

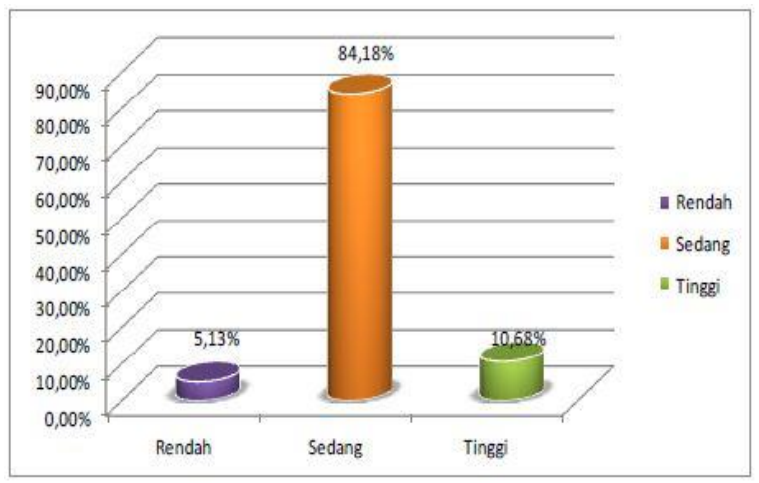

Grafik 1. Keterlibatan Orang Tua dalam Mengembangkan Kemampuan Membaca pada Anak Usia Dini di Kecamatan Cikole Kota Sukabumi
Posisi Keterlibatan Orang Tua dalam Mengembangkan Kemampuan Membaca pada Anak Usia Dini

Hasil penelitian ditemukan terdapat $10,25 \%$ frekuensi keterlibatan orang tua dalam mengembangkan kemampuan membaca pada anak usia dini berada pada ketegori tinggi, $74,78 \%$ frekuensi keterlibaan orang tua dalam mengembangkan kemampuan membaca pada anak usia dini berada pada ketegori rendah dan $14,95 \%$ frekuensi keterlibatan orang tua dalam mengembangkan kemampuan membaca pada anak usia dini berada pada ketegori rendah. Sedangkan, untuk intensitas diperoleh data sebesar 2,13\% intensitas keterlibatan orang tua dalam mengembangkan kemampuan membaca pada anak usia dini berada pada ketegori tinggi, 75,64\% intensitas keterlibatan orang tua dalam mengembangkan kemampuan membaca pada anak usia dini berada pada ketegori rendah dan 22,22\% intensitas keterlibatan orang tua dalam mengembangkan kemampuan membaca pada anak usia dini berada pada ketegori rendah. Untuk lebih jelasnya grafik 2. berikut menyajikan posisi keterlibaan orang tua dalam mengembangkan kemampuan berdasarkan frekuensi (perminggu) dan intensitas (dalam hitungan jam) keterlibatan orang tua dalam mengembangkan kemampuan membaca pada anak usia dini di Kecamatan Cikole Kota Sukabumi. 


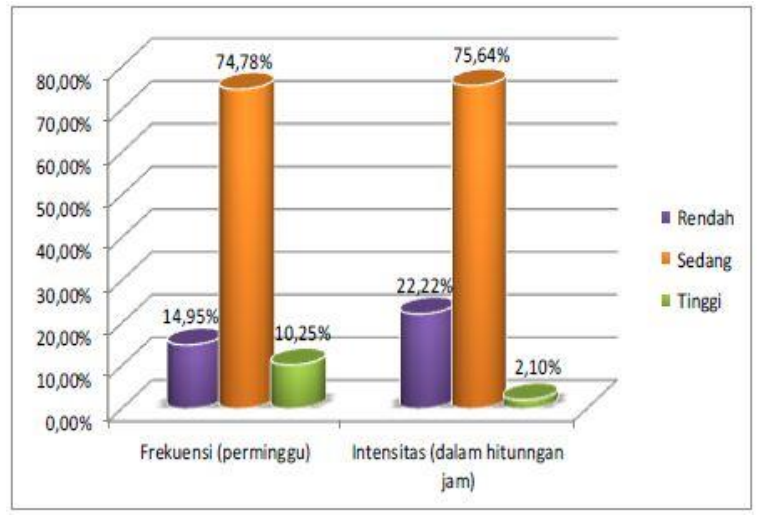

Grafik 2. Posisi Keterlibatan Orang Tua dalam Mengembangkan Kemampuan Membaca pada Anak Usia Dini di Kecamatan Cikole Kota Sukabumi.

\section{Alasan Orang Tua Mengenai Keterlibatannya dalam Mengembangkan Kemampuan Membaca pada Anak Usia Dini}

Hasil penelitian menunjukan bahwa berdasarkan alasan orang tua terlibat dalam mengembangkan kemampuan membaca pada anak usia dini diperoleh bahwa pada alasan yang pertama yaitu kesedian waktu yang dimiliki orang tua untuk terlibat dalam mengembangkan kemampuan membaca pada anak usia dini terdapat $8,97 \%$ berada pada kategori rendah, $71,79 \%$ berada pada kategori sedang dan 19,23\% berada pada kategori tinggi. Alasan yang kedua orang tua terlibat dalam mengembankan kemampuan membaca pada anak usia dini yaitu alasan berdasarkan kemampuan sosial ekonomi orang tua terdapat $6,83 \%$ berada pada kategori rendah, $37,60 \%$ berada pada kategoi sedang dan $55,55 \%$ berada pada kategori tinggi. Alasan yang ketiga yaitu alasan orang tua terlibat dalam mengemabangkan kemampuan membaca anak dilihat dari segi fasilitas yang mendukung terdapat $9,4 \%$ berada pada kategoi rendah, $51,70 \%$ berada pada kategori sedang dan $38,88 \%$ berada pada kategori tinggi. Untuk lebih jelasnya grafik 3 berikut menyajikan alasan orang tua mengenai keterlibatannya dalam mengembangkan kemampuan membaca pada anak usia dini di Kecamatan Cikole Kota Sukabumi

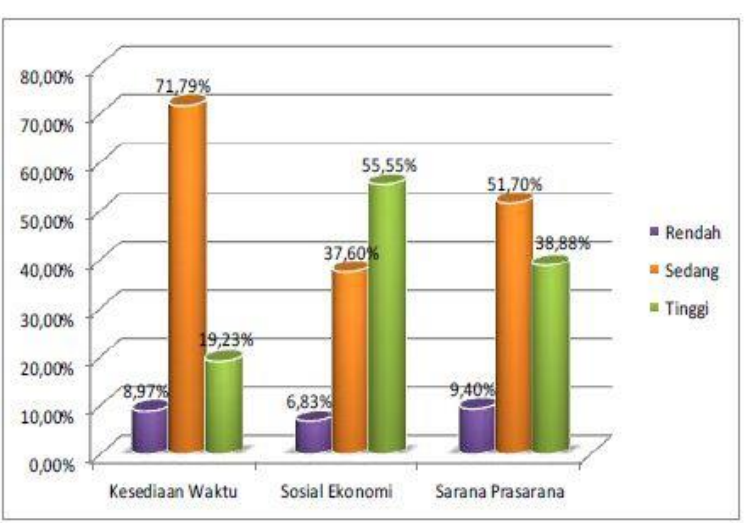

Grafik 3 Alasan Orang Tua Mengenai Keterlibatannya dalam Mengembangkan Kemampuan Membaca pada Anak Usia Dini Kecamaan Cikole Kota Sukabumi

Usaha yang Dilakukan Orang Tua dalam Mengembangkan Kemampuan Membaca pada Anak Usia Dini

Hasil penelitian menunjukan bahwa berdasarkan usaha yang dilakukan orang tua dalam mengembangkan kemampuan membaca pada anak usia dini diperoleh bahwa pada usaha yang ke satu yaiu pemberian perhatian pada pembelajaran anak terdapat $8,97 \%$ usaha orang tua berada pada kategori rendah, $56,41 \%$ usaha orang tua berada pada kategori sedang dan $34,61 \%$ usaha orang tua berada pada kategori tinggi. Usaha yang ke dua yaitu bercakap-cakap, membaca dan berceria terdapat 19,65\% usaha orang tua berada pada kaegori rendah, $66,23 \%$ usaha orang tua berada pada 
kategori sedang dan $14,10 \%$ usaha orang tua berada pada kategori tinggi. Usaha yang ke tiga yaitu mencipakan bacaan terdapat $16,66 \%$ usaha orang tua berada pada kaetgori rendah, $78,20 \%$ usaha orang tua berada pada kategori sedang dan 5,12\% usaha orang tua berada pada kategori tinggi. Usaha yang ke empat yaitu menulis bacaan dalam buku harian terdapat $10,25 \%$ orang tua berada pada kategori rendah, 76,49\% usaha orang tua berada pada kategori sedang dan $13,24 \%$ usaha orang tua berada pada kategori tinggi. Usaha yang ke lima yaitu terus membina keluarga pembaca terdapat $9,82 \%$ orang tua berada pada kaetgori rendah, 75,21\% usaha orang tua berada pada kategori sedang dan $14,95 \%$ usaha orang tua berada pada kategori tinggi. Dan untuk usaha yang ke enam yaitu memperhatikan kelemahan anak dalam membaca terdapat $14,95 \%$ orang tua berada pada kategori rendah, $70,94 \%$ usaha orang tua berada pada kategori sedang dan $14,10 \%$ usaha orang tua berada pada kategori tinggi. Untuk lebih jelasnya grafik 4 berikut menyajikan usaha yang dilakukan orang tua dalam mengembangkan kemampuan membaca pada anak usia dini di Kecamatan Cikole Kota Sukabumi.

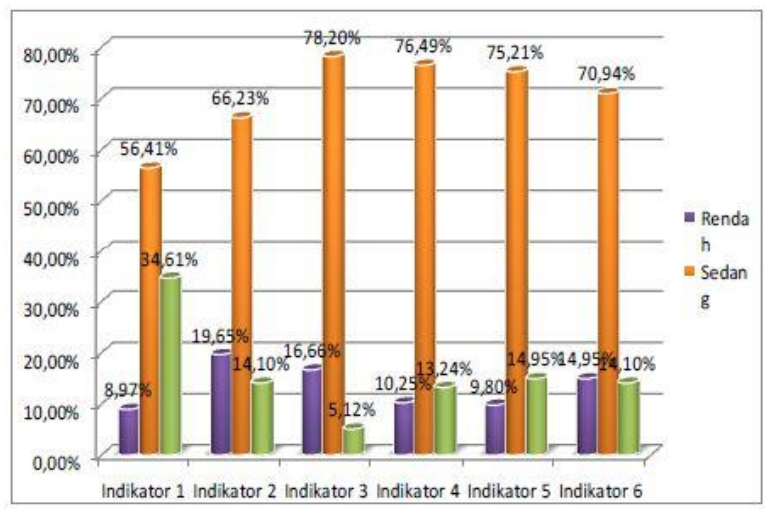

Grafik 4. Usaha yang Dilakukan Orang Tua dalam Mengembangkan Kemampuan Membaca pada

\section{Anak Usia Dini di Kecamatan Cikole Kota Sukabumi}

\section{Hambatan Yang Dihadapi Orang Tua dalam Mengembangkan Kemampuan Membaca pada Anak}

Hasil penelitian menunjukkan bahwa terdapat $65,38 \%$ faktor eksogen yang menghambat keterlibatan orang tua dalam mengembangkan kemampuan membaca anak berada dalam kategori rendah dan $34,61 \%$ faktor eksogen yang menghambat keterlibatan orang tua dalam mengembangkan kemampuan membaca anak berada daam kategori rendah. Selain faktor eksogen terdapat pula faktor endogen dalam diri anak yang menghambat kerlibatan orang tua dalam mengembangkan kemampuan membaca pada anak, menurut hasil penelitian terdapat $60,25 \%$ fakor endogen yang menghambat keterlibatan orang tua dalam mengembangkan kemampuan membaca anak berada daam kategori tinggi dan 39,74\% fakor endogen yang menghambat keterlibatan orang tua dalam mengembangkan kemampuan membaca anak berada dalam kategori rendah. Untuk lebih jelasnya diagram 5 berikut menyajikan hambatan yang dihadapi orang tua dalam mengembangkan kemampuan membaca pada anak usia dini di Kecamatan Cikole kota Sukabumi.

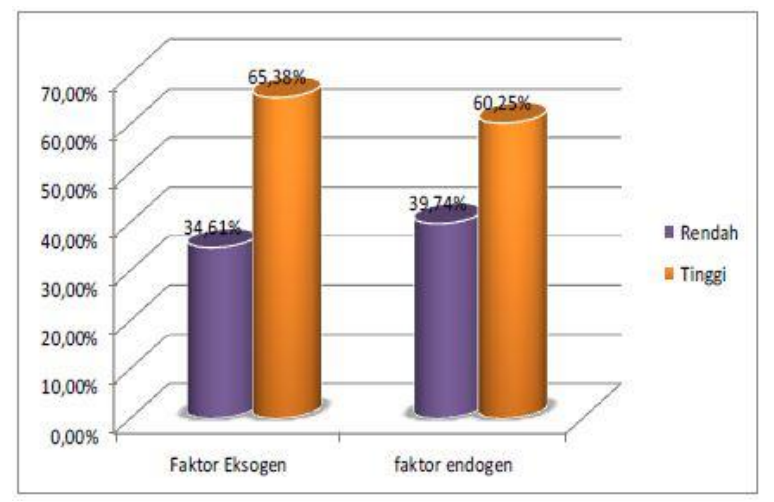


Grafik 5. Hambatan Yang Dihadapi Orang Tua dalam Mengembangkan Kemampuan Membaca pada Anak di Kecamatan Cikole Kota Sukabumi.

Keluarga terutama ayah atau ibu merupakan sosok pemeran utama dalam menstimulasi perkembangan kehidupan seorang anak termasuk perkembangan kemampuan membaca anak. Hasil penelitian menunjukan bahwa secara umum keterlibatan orang tua di Kecamatan Cikole Kota Sukabumi berada pada kategori rendah sebesar 10,68\%, kategori sedang sebesar $84,18 \%$ dan $5,12 \%$ berada dikategori tinggi. Ini berarti bahwa mayoritas orang tua di Kecamatan Cikole Kota Sukabumi memiliki keterlibatan yang sedang terhadap keterlibatan mereka dalam mengembangkan kemampuan membaca pada anak usia dini yaitu sebesar $84,18 \%$, ini berarti bahwa hanya sebagian kecil saja orang tua di Kecamatan Cikole Kota Sukabumi yang telah benar-benar terlibat dalam mengembangkan kemampuan membaca pada anak usia dini. Padahal keterlibatan orang tua akan sangat berdampak positif terhadap perkembangan anak terutama perkembangan membaca, hal ini sependapat dengan pendapat yang dikemukakan oleh Meece, Seneschal \& Lefevre (dalam Schunk, 2012) ada banyak bukti yang mendukung hipotesis bahwa kualitas pemelajaran awal seorang anak di lingkungan keluarga berkaitan positif dengan perkembanga intelegensi dan keterampilan membaca. Kesimpulan keterlibatan orang tua secara umum dalam mengembangkan kemampuan membaca pada anak usia dini di Kecamatan Cikole Kota Sukabumi ini, diperoleh dari hasil uraian sebagai berikut:

\section{Posisi Keterlibatan Orang Tua dalam Mngembangkan Kemampuan Membaca pada Anak Usia Dini}

Dari hasil perhitungan kuantitatif yang telah dilakukan untuk melihat posisi keterlibatan orang tua yang dilihat dari segi perhitungan frekuensi (perminggu) dan intensitas (hitungan jam) di Kecamatan Cikole Kota Sukabumi berada pada posisi keterlibatan yang sedang yaitu $74,78 \%$ (frekuensi) dan $75,64 \%$ (intensitas). Terdapat beberapa penyebab terjadinya kondisi ini, seperti orang tua yang belum menyadari pentingnya keterlibatan mereka dalam mengembangkan kemampuan membaca pada anak usia dini. Padahal untuk membantu dalam proses mengembangkan kemampuan membaca anak, diperlukan peranan lingkungan keluarga yang mendukung, teruama dukungan orang tua. Selain itu juga, kebanyakan orang tua belum memiliki keteraturan dan kesanggupan dalam keterlibatan mereka dalam mengembangkan kemampuan membaca pada anak. Banyak orang tua terlibat dalam mengembangkan kemampuan membaca namun keterlibatan mereka masih belum teratur dalam hitungan permingggu, atau pula banyak orang tua yang telah teratur dalam mengembangkan kemampuan membaca dalam hitungan perminggu namun belum teratur dalam hitungan perjam.

Keterlibatan orang tua orang tua dalam mengembangkan kemampuan membaca terutama pada usia dini (0-6 tahun) akan memberikan dampak yang positif terhadap kemampuan membaca anak. Seperti yang diungkapkan oleh Park (dalam Pradipta, 2014, hlm. 10) menjelaskan bahwa keterlibatan orang tua memiliki pengaruh positif dalam mengembangkan kemampuan literasi anak. 


\section{Alasan Orang Tua Mengenai Keterlibatannya dalam Mengembangkan Kemampuan Membaca pada Anak Usia Dini}

Hasil dari perhitungan kuantitatif yang telah dilakukan dapat diketahui bahwa persentase terbesar dari alasan ketersediaan waktu yang dimiliki orang tua dalam mengembangkan kemampuan membaca berada pada kategori sedang yaitu sebesar $71,79 \%$, ini berarti bahwa alasan keterlibatan orang tua dalam mengembangkan kemampuan membaca pada anak usia dini dipengaruhi oleh kesediaan waktu yang dimiliki orang tua berada pada kategori sedang. Penyebab alasan keterlibatan orang tua di kecamatan Cikole kota Sukabumi sedang itu sebabkan karena, kebanyakan orang tua belum mampu menyediakan waktu luang meraka untuk melibatkan diri dalam mengembangkan kemampuan membaca anak, mereka belum mampu memanfaatkan waktu luang yang mereka miliki untuk kepentingan anak, mereka lebih senang menggunakan waktu luang mereka dengan bersantai atau memanfaatkan waktu luang mereka untuk kepentingan, kesenangan, dan kepuasan diri mereka sendiri.

Alasan yang kedua yaitu alasan orang tua dalam keterlibatannya mengembangkan kemampuan membaca pada anak usia dini berdasarkan alasan kemampuan sosial ekonomi orang tua. Dari hasil penelitian diperoleh mayoritas alasan orang tua di Kecamatan Cikole Kota Sukabumi terlibat dalam mengembangkan kemampuan membaca anak usia dini karena alasan sosial ekonomi berada pada kategori tinggi dengan skor $55,55 \%$. Ini berarti bahwa meskipun mayoritas keterlibatan orang tua dalam mengembangkan kemampuan membaca anak di Kecamatan Cikole Kota Sukabumi berada pada kategori tingg, artinya bahwa alasan sosial ekonomi merupakan alasan yang sering dijadikan alasan orang tua ikut terlibat dalam mengembangkan kemampuan membaca pada anak usia dini. Tuntutan jaman saat ini menuntut tidak hanya seorang ayah yang bekerja diluar rumah tetapi juga menuntut kebanyakan ibu bekerja di luar rumah sehingga mereka tidak mampu meluangkan waktu untuk terlibat dalam mengembangkan kemampuan membaca anak karena terlalu sibuk dengan pekerjaan yang mereka lakukan. Meece (dalam Schunk, 2012, hlm 425) menyatakan bahwa Orang tua yang memiliki status sosial ekonomi rendah memiliki sedikit sumber daya dalam mendukung pembelajaran anakanak mereka diluar sekolah, dibandingkan dengan keluaraga berstatus sosial ekonomi lebih tinggi. Keluarga dengan status sosial rendah akan sulit terlibat dalam mengembangkan kemampuan perkembangan anak-anak mereka terutama kemampuan membaca, hal ini disebabkan karena bebrapa faktor terutama karena kesibukan orang tua untuk menaikan status sosial ekonomi mereka.

Alasan yang ketiga mengenai alasan orang tua terlibat dalam mengembangkan kemampuan membaca pada anak dilihat dari segi fasilitas yang mendukung, terdapat kategori sedang dari alasan orang tua dalam mengembangkan kemampuan membaca anak usia dini dilihat dari segi fasilitas yang mendukung yaitu terdapat sekitar 51,70\% dengan nilai interpratasi skor cukup. Ketersediaan fasilitas yang mendukung sebenarnya merupakan salah satu faktor pengembang kemampuan membaca anak, seperti yang diungkapkan oleh Musfiroh (dalam Amariana, 2012, hlm. 10) bahwa keterlibatan orangtua dapat diartikan dengan cara pemberian stimulasi (fasilitas) oleh orangtua kepada anak usia dini. Fasilitas 
yang lengkap akan menstimulasi anak untuk beraktivitas literasi dan menanamkan minat literasi, hal ini dikarenakan fasilitas yang lengkap akan selalu memacu anak untuk selalu ingin tahu penggunaan fasilitas yang ada. Dengan ketersediaannya fasilitas yang menarik akan dapat menstumulasi anak untuk lebih tertarik dalam mengembangkan kemampuan membaca bersama orang tua, sehingga orang tua tidak akan sulit mengajak anak untuk ikut menegmbangkan kemampuan membacanya.

\section{Usaha yang Dilakukan Orang Tua dalam Mengembangkan Kemampuan Membaca pada Anak Usia Dini}

Menurut Tampubolon (1993, hlm. 82) terdapat beberapa usaha yang dapat dilakukan oerang tua dalam mengembangkan kemampuan membaca pada anak usia dini. Diantaranya memberikan perhatian pada pembelajaran anak, bercakap-cakap, membaca, dan bercerita, menciptakan bacaan, menulis pengalaman dalam buku harian, terus membina keluarga pembaca, memperhatikan kelemahan anak dalam membaca. Berikut akan dijelaskan hasil dari penelitian yang telah dilakukan terhadap usaha yang dilakukan orang tua di Kec. Cikole Kota Sukabumi dalam mengembangkan kemampuan membaca pada anak usia dini.

Dari data hasil perhitungan kuantitatif yang telah dipaparkan sebelumnya dapat diketahui bahwa mayoritas rata-rata usaha yang dilakukan orang tua dalam mengembnagkan kemampuan membaca anak usia dini berada pada kategori sedang dengan iterpretasi skor dari cukup hingga kuat, sedangkan untuk usaha yang dilakukan orang tua dalam mengembangkan kemampuan membaca dengan kategori tinggi hanya berada pada interpretasi skor lemah hingga sangat lemah. Ini berarti bahwa usaha orang tua di kecamatan Cikole kota Sukabumi yang dilakukan dalam mengambangkan kemam-puan membaca anak usia dini masih belum maksimal, orang tua belum sepenuhnya melakukan usahausaha yang dapat mengembangkan kemampuan membaca anak usia dini.

Beberapa bentuk usaha yang dapat dilakukan orang tua telah dipaparkan sebelumnya di atas, tinggal bagaimana orang tua dapat menjalankan dan mencoba melakukan bentuk usaha-usaha tersebut. Beberapa usaha yang telah dipaparkan sebelumnya merupakan usaha yang mudah dilakukan oleh orang tua. Orang tua yang memahami akan pentingnya mengembangkan kemampuan membaca pada anka usia dini akan melakukan usaha-usaha guna mendukung keterlibatan orang tua dalam mengembangkan kemampuan membaca pada anak usia dini, orang tua akan terlibat dengan variasi, baik secara fasilitas, aktivitas dan kebiasaan yang dilakukan.

\section{Hambatan yang Dihadapi oleh Orang Tua dalam Mengembangkan Kemam- puan Membaca Anak}

Kelemahan membaca yang biasa dialami seorang anak mungkin akan menjadi penghambatan keterlibatan orang tua dalam mengembangkan kemampuan membaca anak karena faktor yang berasal dari anak itu sendiri, faktor penghambat ini yaitu faktor eksogen dan faktor endogen.

Hasil peneliian menunjukan bahwa terdapat $65,38 \%$ faktor eksogen yang menghambat keterlibatan orang tua dalam mengembangkan kemampuan membaca anak berada dalam kategori tinggi dan $34,61 \%$ faktor eksoen yang menghambat keterlibatan orang tua dalam mengembangkan kemampuan membaca 
anak berada kategorii rendah. Sedangka untuk faktor endogen diperoleh 60,25\% faktor endogen yang menghambat keterlibatan orang tua dalam mengembangkan kemampuan membaca anak berada dalam kategori tinggi dan $39,74 \%$ faktor endogen yang menghambat keterlibatan orang tua dalam megembangkan kemampuan membaca anak berada pada kategori rendah.

Hasil penelitian tersebut memperlihatkan bahwa kebanyakan mayoritas orang tua dari sampel di Kec. Cikole Kota Sukabumi merasa kesulitan menghadapi anak-anak dengan hambatan dari faktor eksogen dibandingkan endogen. Ini berati orang tua merasa lebih kesulitan menghadapi rasa malas yang dihadapi anak dibandingkan masalah yang memang timbul akibat keterbatasan yang dimiliki anak. Faktor eksogen merupakan faktor yang timbul dari lingkungan, lain halnya dengan faktor endogen yang timbul dari dalam diri anak sendiri. Kebayakan orang tua akan merasa jengkel ketika menghadapi anak mereka yang sulit diajak dalam kegiatan mengembangkan kemampuan membaca karena terlalu asik dengan kegiatannya bermain. Rasa jengkel yag timbul dalam diri orang tua akan menimbulkan rasa putus asa dan menyerah. Rasa putus asa dan menyerah ini lama kelamaan akan menimbulkan rasa malas pula pada orang tua dalam kegiatan mengembangkan kemampuan membaca anak, sehingga orang tua akan enggan untuk diajak mengembangkan kemampuan membca anak.

\section{SIMPULAN}

Berdasarkan pada penjelasan bab sebelumnya mengenai keterlibatan orang tua dalam mengembangkan kemampuan membaca pada anak usia dini di Kecamatan
Cikole Kota Sukabumi, maka dari data penelitian terhadap 234 sampel menghasilkan kesimpulan bahwa secara umum keterlibatan orang tua di Kecamatan Cikole Kota Sukabumi berada pada kategori sedang dengan interpretasi skor tinggi, hasil ini diperoleh dari beberapa kesimpulan uraian, sebagai berikut:

1. Dari hasil penelitian dapat diketahui bahwa mayoritas dari posisi orang tua dalam mengembangkan kemampuan membaca pada anak usia dini di Kecamatan Cikole Kota Sukabumi berada pada kategori sedang dengan interpretasi skor kuat, artinya bahwa mayoritas kebanyakan orang tua di Kecamatan Cikole Kota Sukabumi memiliki keterlibatan yang sedang dalam mengembangkan kemampuan membaca pada anak usia dini.

2. Dari hasil penelitian dapat diketahui bahwa alasan orang tua di kecamatan Cikole kota Sukabumi terlibat dalam mengembangkan kemampuan membaca pada ank usai dini dilihat dari segi kesediaan wantu orang tua berada pada kategori sedang dengan interpretasi kuat, alasan yang kedua yaitu alasan orang tua di kecamatan Cikole kota Sukabumi terlibat dalam mengembangkan kemampuan membaca pada ank usai dini dilihat dari segi sosial-ekonomi orang tua berada pada kategori tinggi dengan interpretasi cukup dan yang alasan yang ketiga yaitu alasan orang tua terlibat dalam mengembangkan kemampuan membaca pada ank usai dini dilihat dari segi fasilitas yang mendukung berada pada kategori sedang dengan interpretasi skor cukup.

3. Dari hasil informasi mengenai usaha yang dilakukan orang tua di kematan Cikole kota Sukabumi bahwa rata-rata usaha yang dilakukan orang tua berada 
pada kategori sedang dengan interpretasi kuat, sedangkan untuk usaha memperhatikan pembelajaran anak berada pada kategori sedang dengan interpretasi skor cukup.

4. Dari hasil penelitian di peroleh informasi bahwa peningkatan tahap perkembangan membaca anak karena keterlibatan orang tua di kecamatan Cikole kota Sukabumi berada pada kategori sedang dengan interpretasi skor cukup, dan termotivasinya anak dalam mengembangkan kemampuan membaca karena keterlibatan orang tua berada pada kategori sedang dengan interpretasi cukup.

5. Hambatan yang dihadapi oleh orang tua dalam mengembangkan kemampuan membaca di Kecamatan Cikole Kota Sukabumi dalam mengembangkan kemampuan membaca pada anak usia dini, menjadi dua faktor, yaitu faktor endogen dan faktor eksogen. Dari hasil penelitian dapat diketahui bahwa mayoritas orang tua di Kec Cikole Kota Sukabumi lebih merasa kesulitan menghadapi anak-anak dengan hambatan yang berasal dari faktor eksogen dibandingkan endogen.

\section{DAFTAR PUSTAKA}

Amariana, Ainin.(2012). Keterlibatan orang tua dalam perkembangan literasi anak usia dini. online]. Diakses dari http://eprints.Ums.ac.id/20334/13NAS KAH_PUBLIKASI.pdf\&sa $=$ U\&ved $=0$ CAYQFJAAahUKEwixsMzk79TIAh UG4mMKHWogDOw\&usg=AFQjCN H-zplOno8OM4318sff33ANNQtc6W

Dariyo, Agoes. (2007). Psikologi perkembangan anak usia iga ahun perama. Bandung: Refika Adiama

Mutiah, Diana. (2012). Psikologi Bermain Anak Usia Dini. Jakarta: Kencana Prenada Media Group

Pradipta, Galuh Amithya. Januari 2014. Keterlibatan orang tua dalam proses mengembangkan literasi Dini Pada Anak Usia PAUD di Surabaya. Unair journal. Volume 3, no.1. http://journal.unair.ac.id/article_6443_ media136_category.html, 25 Mei 2014.

Schunk, D. H., Pintrich, P. R., Meece, J. L. (2012). Motivasi dalam Pendidikan: Teori, Penelitian, dan Aplikasi (Edisi Ketiga). Jakarta: PT Indeks

Tampubolon. (1993). Mengembangkan Mina Dan Kebiasaan Membaca Pada Anak. Bandung: Agkasa

Tom \& Harriet Sobol. (2003). Rancang bangun anak cerdas. Jakara: Inisiasi Press

Wahyudin, uyu dan Mubiar Agustin (2012). Penilaian Perkembangan Anak Usia Dini. Bandung: Refika Aditama 